\title{
Lacunas in the Preparation of Nepal for COVID-19 till the Third Stage of Disease Transmission
}

\author{
Bishnu Dev Pant ${ }^{1}$, Sharad Chand ${ }^{2}$, Sophia M George², Nandakumar UP², Pukar Khanal ${ }^{3}$, CS Shastry², Sujit Kumar Sah", \\ Ramesh Datta Pant ${ }^{5}$, Jeevan Bhatta ${ }^{6}$, Jeet Bahadur Moktaan7, Sunil Nepal ${ }^{8}$, Ramesh Bhandari ${ }^{9, *}$, Sujan Basnet ${ }^{10}$ \\ 'Purbanchal University, Faculty of Medical and Allied Sciences, Hope International College, Public Health Program, NEPAL. \\ 2Department of Pharmacy Practice, NGSM Institute of Pharmaceutical Sciences, NITTE (Deemed to be University), Paneer, Deralakatte, Mangaluru, Karnataka, INDIA. \\ 3Department of Pharmacology and Toxicology, KLE College of Pharmacy, Belagavi, KLE Academy of Higher Education and Research (KAHER), Belagavi, \\ Karnataka, INDIA. \\ ${ }^{4}$ Department of Pharmacy Practice, JSS College of Pharmacy (JSS Academy of Higher Education and Research) SS Nagar, Mysuru, Karnataka, INDIA. \\ ${ }^{5}$ Covance India Pharmaceutical Services Private Limited, Bengaluru, Karnataka, INDIA. \\ ${ }^{6}$ Program Officer, Nepal Public Health Association, Kathmandu, NEPAL. \\ 'Department of Pharmacy Practice, Sri Adichunchanagiri College of Pharmacy, Adichunchanagiri, University, BG Nagara, Karnataka, INDIA \\ ${ }^{8}$ Department of Clinical Pharmacy, School of Health and Allied Sciences, Pokhara University, NEPAL. \\ 'Department of Pharmacy Practice, KLE College of Pharmacy, Belagavi, KLE Academy of Higher Education and Research (KAHER), Belagavi, Karnataka, INDIA. \\ ${ }^{10}$ School of Public Health, University of Alberta, Edmonton, AB, CANADA.
}

\begin{abstract}
The novel coronavirus was renamed as coronavirus disease 2019 (COVID-19) by the world health organization, began its spread in December 2019, in the city of Wuhan, China. Global bodies and governments weren't prepared to handle the impact of the virus on society. Nepal's landlocked nation encountered its incident confirmed case of COVID-19 during the first week of January, with the primary host being a student with a travel history from its place of inception. The nation is deficient in its health resources. The country mainly focused on the stringent implementation of washing of hands, wearing masks, restricting general movement, and maintaining social distancing in public. The disease transmission reached to the third stage, which began within three months after the confirmation of the first case of COVID-19. The lack of tropical hospitals, laboratory and diagnostic facilities added to the challenges faced by the country. This paper is a
\end{abstract}

comprehensive review of the overall preparation and steps taken by the federal system of Nepal to combat the virus's effects till the third stage of transmission. It concludes with the practical limitations faced by the governing authorities of the nation while implementing these measures. Key words: Nepal, COVID-19, Preparedness, Lockdown, Migrant labor.

\section{Correspondence}

Dr. Ramesh Bhandari,

Department of Pharmacy Practice, KLE College of Pharmacy, Belagavi, KLE Academy of Higher Education and Research (KAHER), Belagavi, Karnataka, INDIA.

Email: ramesh_2417@yahoo.com

DOI: 10.5530/jyp.2021.13.21

\section{INTRODUCTION}

Coronaviruses belong to a family named Coronaviridae having crownlike projections that are present in their envelope and these protrusions are responsible for causing the disease. After a prolonged time interval of almost a decade, these viruses have returned to generate a worldwide pandemic across the globe. This family of viruses has been named differently at separate time points of their incidence. At each of their distinct points of occurrence, they have been referred to as the severe acute respiratory syndrome by SARS-CoV (2002), sometimes as the middle east respiratory syndrome by MERS-CoV (Middle Eastern countries-2012) and is currently known as the coronavirus disease whose etiology has been confirmed to be the SARS-CoV-2 (2019). ${ }^{1-3}$

The incident case was first reported as "A pneumonia of unknown etiology" in Wuhan, in the Hubei Province of China in late December 2019. The world health organization (WHO) renamed the coronavirus as COVID-19 on $11^{\text {th }}$ February $2020 .{ }^{1}$ Due to the swift spread of infection, the WHO declared the disease to be a public health emergency on $30^{\text {th }}$ January 2020, which was soon given the status of a pandemic by $11^{\text {th }}$ March owing to its transmission across 114 nations infecting 118,000 people. The virus is believed to have its source of origin and transmission through the wild animals of the wet market in China. ${ }^{1}$ It has been proved that human to human transmission occurs through droplets while coughing or sneezing. This results in the manifestation of preliminary respiratory symptoms such as fever, cough, sore throat, dyspnea and malaise during the initial stages followed by systemic symptoms that may arise during the complicated stages of the disease. The disease is found to peak in severity in patients with co-morbid conditions such as cardiovascular and respiratory diseases, metabolic disorders and in subjects with pre-existing renal disease. ${ }^{2}$ The average duration of incubation needed by the pathogen to display clinical signs and symptoms after its entry into the host is five days and it may range from 2 to 14 days. $^{1-3}$

Nepal, a landlocked country, shares its northern borders with Tibet, an autonomous region of the People's Republic of China, while the other three national boundaries are shared with India wherein, no visa is required for travel and migration. ${ }^{4}$ The federal structure of Nepal comprises of one central government that governs seven provinces along with six metropolitan and 11 sub-metropolitan cities. The municipal system of the country is equipped with vocationally trained paramedic health service providers that coordinate with various provinces and the federal government. ${ }^{4}$ With a total population of $29,218,867$, as of 2018 , Nepal has a per capita income of US\$ 1034 (2018/19) and a human development index of 0.579 (2019) which ranks the nation at the $147^{\text {th }}$

This is an open access article distributed under the terms of the Creative Commons Attribution-NonCommercial-ShareAlike 4.0 License, which allows others to remix, tweak, and build upon the work non-commercially, as long as the author is credited and the new creations are licensed under the identical terms. 
position in the global scenario. ${ }^{5}$ Human labor that is employed in foreign countries with a valid work permit are 4,365,415 (f/y 2017/18). However, this statistic does not include laborers that are working in India due to the open borders between the two nations. Nepal is a nation with the potential to attract a large tourist population, with the country recording the total number of tourist arrivals excluding Indians to be $1,173,072$ in the year 2018.

The Nepal Medical Council has a total registered number of 23,146 MBBS graduates, 7,185 MD/MS and 3773 dental doctors. ${ }^{7}$ The sum of those registered in the Nepal health professional council for general medicine (paramedics) stands at 88,782 , six thousand seven hundred six public health professionals and 3,648 healthcare staff trained in the field of radiology/imaging. ${ }^{8}$ The number of registered nurses in possession of a renewed certificate is a grand total of $24,822 .{ }^{9}$

The distribution of clinicians is unequal, although there may be a significant number of licensed physicians working across the country. Doctors are majorly centralized in the Kathmandu valley, where the doctor to patient population ratio stands at 1:850 and a striking ratio $1: 150,000$ exists in rural areas. Hence, there is a severe deficiency of doctors for the national population and it is reflected in a calculated ratio of $1: 1724 . .^{10}$

\section{PREPARATIONS DURING THE FIRST STAGE OF DISEASE TRANSMISSION}

The incident case of COVID-19 in Nepal was an individual from Wuhan, who was a Nepalese citizen returning home. The suspect voluntarily visited the Tropical and Infectious Disease hospital on $13^{\text {th }}$ January. $\mathrm{He}$ was free of any other co-morbidity and presented only with the symptom of cough that developed while in China. After a positive report was confirmed, the WHO designated laboratory ordered the patient to be isolated for four days following which, he was discharged with counseling to stay confined in-home quarantine. After two successive negative swab reports were obtained by the end of January, he was announced as cured. ${ }^{11}$ Even after a period of 21 days, those who came in contact with the individual did not manifest any symptoms and hence, it was concluded that there were no transmissions from him. No follow up contact tracing was done for further confirmation. ${ }^{4,11}$ The sole international airport of Nepal was facilitated with a standby ambulance which was kept ready, especially for the treatment of sufferers. Thermal scanning and counseling were done throughout the day on a regular basis. The central government was in continuous communication with the provincial governments encouraging them to effectively implement measures for the management of the COVID-19 patients. All central and periphery hospitals were kept on standby in case of the sudden emergence of cases. ${ }^{11-13}$

In the second week of March, after WHO announced COVID-19 to be a global pandemic, ${ }^{1}$ a provincial medical emergency group was swiftly prepared to stay on high alert and ready for immediate action. All programs that were related to foreigners working for the nation were temporarily suspended. In order to increase public awareness and clear out misunderstandings related to the infection amongst the general public, toll-free numbers were instituted free of cost by a call center established by the government's telecom company. Fever clinics were set up at all public health facilities and functional testing centers at the provincial level were instituted by early April 2020. Institutional Ethics Committee (IEC) materials were printed and widely distributed throughout the country. Copies of the detailed procedure/ protocol/ standard operating procedures (SOP) for efficient case management, rules governing quarantine, clinics, testing of suspected cases and strict screening procedures were instituted at the entrances of all public places with the inception of COVID-19. After the second week of March, individuals traveling from a pretentious country needed to either be certified free of COVID-19, or they needed to be strictly quarantined for14 days. ${ }^{12,13}$

Nepalese students who were previously in Wuhan were repatriated and restricted to quarantine that was specially established for COVID-19 patients and were discharged within the next 14 days, accompanied with a negative swab test result. ${ }^{11-13}$ On $16^{\text {th }}$ February 2020, a sum total of 175 Nepalese students studying in Wuhan were airlifted to Nepal and quarantined in facilities specially designed for them. All students and crew members were well informed about the prevention techniques to mitigate disease transmission. Students were instructed to maintain a minimum distance of 3 feet while walking and the regular use of masks and sanitizers was made mandatory. Ambulance and central laboratory were kept on standby. The screening process was done by a team lead by the Nepal police at both Wuhan and at the airport in Nepal. Quarantine and isolation was handled by the same team and the disposal of biomedical waste produced within the airplane and the quarantine facilities was handled by the team in charge of waste management. ${ }^{13,14}$

With the aim to promote tourists, a highly ambitious Campaign, "Visit Nepal 2020" and "Sagarmatha Sambad 2020" was organized by the Government of Nepal which was later suspended until further notice. ${ }^{14,15}$ The government had planned to welcome more than 2 million tourists in the year 2020. The government also decided to halt all tourism promotion campaigns and on $13^{\text {th }}$ March, it was resolved to temporarily suspend mountain climbing as well. ${ }^{19}$ With a rising number of migrant laborers returning from India, special precautionary measures were taken by the third week of January with the setup of health desks at the Indo-Nepal border. Nepalese citizens were permitted to enter only after thermal scanning was done at the health desks of the border. In the second week of March, on-arrival visas were put on hold for people of all nations. However, by the third week of the month, authorization was postponed for travelers to gain entry into Nepal from Europe, United Kingdom, West Asia and Middle Asia, which were much more pretentious through the airway route with COVID-19. By the end of the third week of March, all educational institutions conducting examinations were suspended until further notice by. In order to avoid public gatherings, the national assembly meeting was also suspended until the next announcement. ${ }^{15,16}$

A group of more than 25 people was prohibited from assembling in any community residence. When the $2^{\text {nd }}$ case was confirmed on the $24^{\text {th }}$ of March, the Government of Nepal announced a complete lockdown requesting its citizens to restrict themselves within their homes unless in case of an emergency. All borders with China and India were closed until further notice. ${ }^{17}$ To enhance public awareness of COVID-19, the national telephone company fixed a COVID-19 message of awareness as its caller ring back tone beginning from the second week of March. ${ }^{18} 120$ bedded Intensive Care Unit (ICU) wards were created in the Kathmandu Valley for the treatment of potential COVID-19 patients. Additionally, the committee also declared plans to establish a 1,000-bedded facility of isolation wards at seven hospitals of Kathmandu, which would be facilitated based on the requirement in the future. A decision was made by the cabinet of Nepal at the end of March to accept a loan of $\$ 29$ million from the World Bank, special drawing rights (SDR) of 87.5 million from the International Monetary Fund and $\$ 60$ million from the Asian Development Bank for the nation's fight against COVID-19. During the first stage of COVID preparation, the total number of samples tested using the PCR technique were1,521. The total number of quarantine bed prepared were 27,818 with almost 9,278 patients in isolation. Three thousand one hundred fourteen isolation beds were made available and 54 suspected cases were confined. The most reassuring fact during the first stage of transmission was that Nepal, with its limited resources was able to restrict the number of confirmed cases to just $9 .{ }^{16-19}$ 


\section{PREPARATIONS DURING THE SECOND STAGE OF DISEASE TRANSMISSION UNTIL THE THIRD STAGE}

The second stage of disease transmission started on $4^{\text {th }}$ April 2020, when the $9^{\text {th }}$ case was a relative of the $4^{\text {th }}$ confirmed case and the person was admitted to Seti Provincial Hospital in the Sudurpaschim Province. ${ }^{16,17}$

\section{The major activities done during the second stage include the following:}

On $27^{\text {th }}$ April, the government decided to extend the lockdown across the whole nation. All borders with China and India were closed and international flights were postponed. ${ }^{20}$ During the lockdown, no public transport except the ambulance, fire brigade, security and health personnel were allowed movement. ${ }^{19,20}$ For the validation of the samples, a team comprising of nine participants was formed in collaboration with the Epidemiology and Disease Control Division (EDCD), National Public Health Laboratory (NHPL) and Nepal's Health Research Council (NHRC). An emergency response team at the district level was formed and was functional across the country. As local transmission was seen in the provinces of Sudurpaschim, Gandaki and Nepalgunj, the state equipped itself with high capacity PCR machines in order to enhance its testing capacity. ${ }^{19,20}$

Although the Provincial laboratory was made available with a high capacity RT-PCR machine, the collected samples superseded the available facilities. One hundred ninety-nine samples from Dadeldhura, 425 from Baitadi, 85 from the Karnali province and more samples from the Sudurpaschim provinces were airlifted to the central laboratory. Due to an insufficient number of healthcare workers, it was decided that all those whose careers were funded by the government would be involved to mobilize the control of the COVID-19 crisis. A shift of sample collection was repeated in the province of Sudurpaschim as it opened its border to India from the north and west directions. A total number of 460 samples were collected by the EDCD team and the Nepal army, who airlifted these samples to the central laboratory. By $16^{\text {th }}$ April, 25 central, 64 provincial and 22 medical colleges were functional as COVID-19 clinics. In addition to this, the Kathmandu valley was supplemented with 16 private hospitals. A committee at the provincial level was formed and led by a person nominated by the MoHP who would facilitate coordination among the three levels of government. The crisis was expected to worsen at any time, so additional laboratory staffs in the Kathmandu valley were oriented regarding the testing of COVID-19 using rapid diagnostic test kits and the molecular methods. ${ }^{19-22}$ National labor migrants returning back to their home town from India had a high potential for transmission, especially in the province of Sudurpaschim and hence, a team of 34 medical doctors were mobilized. ${ }^{21-24}$

\section{AT THE SECOND STAGE OF DISEASE TRANSMISSION}

The total number of RT-PCR laboratories throughout the country was expanded to 14. Although testing was done at all labs, suspected cases were confirmed by the central lab alone that reported 32 positive cases. Out of 8,818 samples that were collected, the total numbers of samples that were tested were 8,763 . The information on province-wise quarantine and isolation is detailed in Figures 1 and 2. The department of health services made a public announcement on the $7^{\text {th }}$ April that it was possible for medical products, including PPE kits for the COVID-19 crisis along with 23 medicines to be procured. NGOs were also requested for their aid in the supply of materials needed for the COVID- 19 crisis. ${ }^{22,23}$

\section{NEPAL'S PREPARATIONS DURING THE THIRD STAGE OF DISEASE TRANSMISSION}

The first case appeared in the month of January, but the number of cases began to rise from mid-March. One month later, on $21^{\text {st }}$ April, Nepal was declared to be in the third stage of transmission. The third stage began when COVID-19 positive cases were seen amongst Indian citizens in Udaypur, who was the main source of transmission. ${ }^{15,16}$ On $23^{\text {rd }}$ April, a virtual meeting was arranged by the MoHP with the SAARC countries to discuss measures to prevent the further spread of COVID-19 and to share their experiences. Another meeting with the members of the WHO and PHEOC was held to discuss the same..$^{23,24}$

The next day, a team consisting of a public health officer, laboratory technician, paramedics and nursing staff was formed who would aid in the efficient tracing of contacts. The team was deployed to work at the rural municipality, municipality, sub-metropolitan and metropolitan levels, each consisting of 1,2, 3 and 5 teams, respectively. To tackle the complexity and uncertainty in the management of medical problems associated with COVID-19 and the general patient population, a clinical decision analysis team was formed. Laboratory services were extended across the nation. In order to maintain efficiency, a minimum standard had to be mandatorily maintained in order to give accurate test results. Therefore, a guideline, "Interim Guideline for the establishment and operationalization of molecular laboratory for COVID-19 testing in Nepal" was released. On the same date, SOPs for cleaning and decontamination of ambulances were developed in order to mitigate the transmission through these potential sources of spread. ${ }^{23-25}$

On $13^{\text {th }}$ May, the MoHP recommended the "Pocket Book for Infection Prevention and Control Measures for COVID-19 in the Healthcare Setting" and "Guidelines for COVID-19 Case Investigation and Contact Tracing Team deployment" that would aid in preventing the further rise in COVID cases. Further, after two days, two guidelines were released, namely the "Guideline for the management of frontline health care service

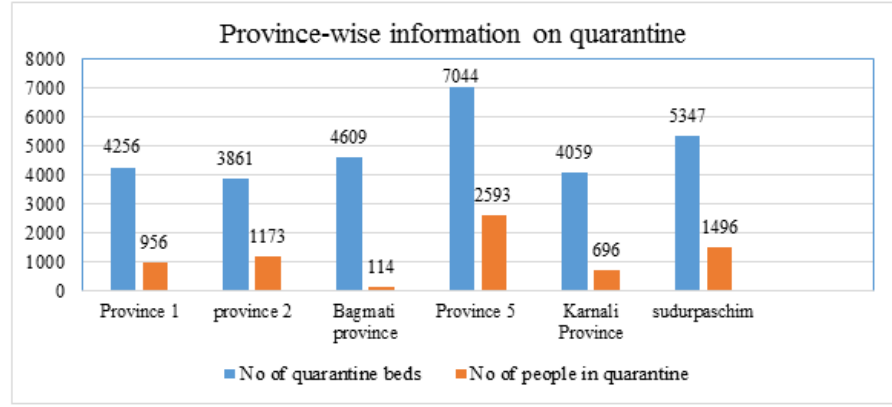

Figure 1: Province-wise information on quarantine.

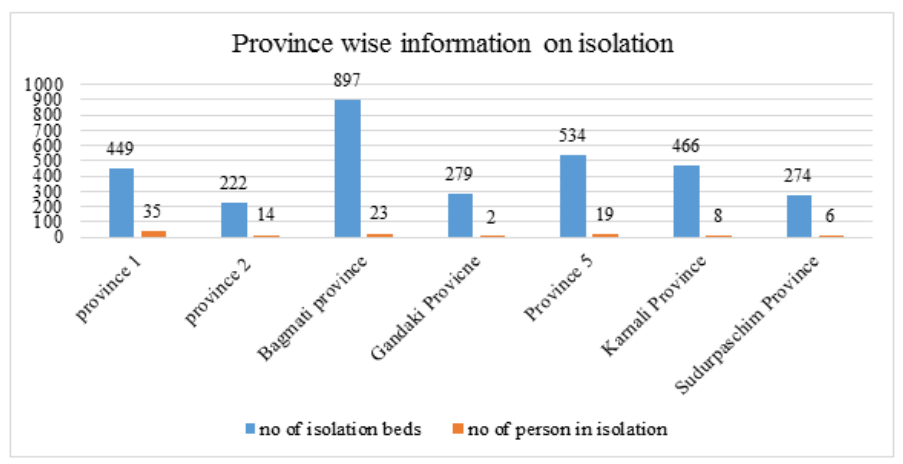

Figure 2: Province-wise information on isolation. 
Pant, et al.: Lacunas in the Preparation of Nepal for COVID-19 till the Third Stage of Disease Transmission

providers and other workers involved in the management of COVID-19 cases, 2077 "and "Interim guideline for permitting private hospitals to test COVID-19 using Rapid Diagnostic Kit (RDT), 2077”. ${ }^{25,26}$ On $20^{\text {th }}$ May, MoHP developed a handbook stating the minimum standards of quarantine and the rules for people inside the quarantine site which would guide the management of the restricted isolation setting. The MoHP framed the "COVID19 Emergency Medical Deployment Teams (EMDT) Mobilization Guidelines". This offered guidance to the staff to organize quarantine, duty shifts and leaves. On $28^{\text {th }}$ May, a guideline to deploy emergency medical teams to different regions of the country was approved by MoHP in order to manage the shortage of human resources. During the first week of June, a protocol to handle deceased COVID-19 patients and a guideline governing the isolation of COVID-19 cases and their management was also developed. ${ }^{26,27}$

By the $1^{\text {st }}$ week of June, national testing guidelines for COVID-19 were developed, which facilitated testing, maintained the standard of the testing site and developed a rationale for testing patients and suspects. $6,871 \mathrm{~kg}$ and $8,156 \mathrm{~kg}$ of equipment respectively was donated by UAE and Qatar for health workers who were front line warriors. A COVID-19 relief fund was established and many organizations, members of parliament and political parties contributed to it too. ${ }^{27-29}$ The fund was established by the provincial government at the provincial level. Simultaneously, the local government was actively engaged in contact tracing and restricting persons to quarantine. The local government also involved in regular coordination with both the provincial and federal governments during testing. They also played a major role in spreading awareness regarding the transmission of the disease and were working on ways to prevent further spread. By the end of March, the council of ministers decided to procure additional medical equipment which was delivered at approximately after 2 months in the month of June. ${ }^{30-33}$

On $17^{\text {th }}$ June, an integrated training on case management, infection prevention, sample collection and transportation, case investigation and contact tracing, RDT testing and techniques guiding the use of PPE was conducted for all health personnel throughout the country according to the guidelines provided by the MoHP. On the same day, ambulances were provided with a separation to prevent transmission of the disease to the driver and other allied health staff. Additionally, a drill display was given to the drivers as an orientation on how to handle COVID cases during transportation. Almost one month after the development of the Interim Guideline for laboratory establishment and testing. With the technical assistance provided by UNICEF, the National Health Training Center at Kathmandu conducted mobile-based training related to COVID-19 for the health workers and Female Community Health Volunteers (FCHV). Additionally, the training center prepared training packages on case investigation and contact tracing (CICT) of COVID-19 and the training was to be implemented at all levels (Federal, Provincial and Local level) beginning from $25^{\text {th }}$ June $2020 .^{33-36}$

In order to maintain uniformity in waste management, 2020 (Interim Guidance) was issued by the MoHP. ${ }^{37}$ The MoHP endorsed home quarantine standards, $2077^{28}$ and approved the treatment of suspected and confirmed COVID cases at private hospitals that are not included in COVID designated hospitals only after mutual coordination and understanding was established between patients and the hospital administration. MoHP also fixed the price of healthcare services per person per day at Rs. 3,500 for mildly symptomatic, Rs 7,000 for moderately symptomatic and Rs. 15,000 for severe and critical cases. The ministry revised the "National testing guidelines for COVID-19", endorsed the Public Health Standards, 2020 to be followed while celebrating festivals, feasts and celebrations during the pandemic and issued standards for the delivery of services of senior citizens in the context of the global pandemic. ${ }^{29,30}$

\section{GAPS IDENTIFIED DURING THE MANAGEMENT OF THE COVID-19 CRISIS IN NEPAL}

Nepal has also implemented the same non-pharmaceutical measures for the prevention and control of COVID-19 transmission as in other countries. The country was able to limit the number of positive cases to a small number up until May 2020. However, during its preparation, some lacunas occurred. Nepal began to ease the nation-wide lockdown with only a few restrictions in place as a result of which the cases began to increase sharply. The preventive measures in place were inadequate while easing the tight restrictions of lockdown. Some of the lacunae are as mentioned below:

\section{Contact tracing and screening was not done for the first case}

The incident case was symptomatic from China for almost one week before traveling to Nepal and he wasn't stopped on screening in the international airport. No contact tracing was done during his journey from the airport to his home. He visited the tropical and infectious disease hospital after a week of his return by himself. He was discharged immediately when the symptoms began to subside without documenting a negative swab result. ${ }^{9-13}$

\section{Delays in procurement}

There arose a global increase in the demand for medical equipment when the pandemic hit almost all countries. It is obviously time consuming to facilitate the supply of medical equipment in this scenario. In the midst of such circumstances, the Government of Nepal processed for the procurement only after 3 months of the first case. The second lot was delivered only after 2 months of placing the order. ${ }^{17,28,29}$

\section{Extreme shortage of equipment}

Nepal touched the second stage of COVID spread after almost 2.5 months but there was a scarcity of PPE kits with merely 30 cases. The global demand for PPE increased by 1 to 2 thousand times compared to the pre-COVID global situation. News posted on $28^{\text {th }}$ March by "The Himalayan Times" stated that the medical officer and nursing staffs of different hospitals throughout the country complained of an inadequate supply of PPE. ${ }^{16,17}$

\section{Inadequate preparations at the border}

Although scanning alone is insufficient to contain the infectiousness of the coronavirus, a huge mob of people entered Nepal without completing even the basic temperature scanning. An exposed border and a free entry at many parts led to a difficulty in monitoring and tracing back people effectively. The stranded population in India was also allowed to return back without much difficulty when the lockdown restrictions were relaxed in India. ${ }^{28-30}$

\section{Lack of sufficient provisions to facilitate COVID-19 testing}

Until $20^{\text {th }}$ of June, there was only one RT-PCR machine in Sudurpaschim (Seti Provincial Hospital). This pathetic situation was not addressed despite the large population and high vulnerability due to the high population of migrant laborers and the open borders of India on both sides. The Karnali province with a comparatively less population of one million, had two RT-PCR laboratories. The province of Bagmati had made arrangements for eight RT-PCRs. Due to the availability of only a 
Pant, et al.: Lacunas in the Preparation of Nepal for COVID-19 till the Third Stage of Disease Transmission

single testing site, very few laboratory tests were done in Sudurpaschim. The number of migrant laborers in quarantine in the province was overwhelming. On the first day of opening the border, 800 individuals underwent RDT for COVID-19 but following the next day, the process of testing by RDT was stopped due to the mass flow of people from India and the existing lack of RDT kits. ${ }^{30-32}$

\section{Inadequate provisions for treatment, quarantine and isolation}

Almost 0.5 to 3 million Nepali labor migrants are currently employed in India. A decision was taken on the date $23^{\text {rd }}$ March 2020 to create provisions for 410,000-548,000 quarantine beds. However, this could not be completed. The existing capacity would not be able to bear the load for the huge mass of immigrant labor. ${ }^{41}$ Since many migrant laborers were forced to leave due to the cancellation of their contracts with companies, migrant laborers from the Middle East countries wanted to immediately return back. The headcount of such individuals amounted to a staggering 127,000 along with 1.3 million workers in the Gulf who planned to return around the same time too. Once international flights are restarted, a high flow of migrant labor is expected to return back. Hence, they would require quarantine facilities managed by the government..$^{32-37}$

\section{Dearth of advanced health care facilities and well- trained human resources}

The WHO standard for a doctor to population ratio suggests that one doctor should be available for a 1000 population, ${ }^{38}$ but Nepal has not been able to meet this standard. In Kathmandu valley, the ratio stands at 1: 850 , but the overall country is highly imbalanced with a ratio of $1: 1724$. In rural areas, the situation is worse as the ratio is $1: 150,000 .^{38}$ The western hills of Nepal have been classified as a high-risk area if the current scenario of insufficient human resources continues.

\section{Insufficient equipment- Lack of ventilators and ICU facilities}

There were only 900 ventilators and 2600 ICU beds until $8^{\text {th }}$ August. These facilities will not be sufficient if the total number of cases cross 10,000 , assuming that $5 \%$ confirmed cases might need ventilation. Additional ventilators might also be needed for non-COVID patients. ${ }^{39}$

\section{Standards of quarantine}

Quarantine centers were established by every local government. These constructions did not meet the set standards of WHO. They lacked proper provisions for food, lodging and water. This occurred due to the low budget, insufficient human resources and quarantine facilities made in school buildings. ${ }^{40}$

\section{Lack of coordination between three levels of the government}

As Nepal adopted federalism recently, they were not able to efficiently organize the health structure and hence, lacked coordination among the three tiers of government. ${ }^{41}$

\section{Mobilization of FCHV}

Female community health volunteers(FCHV)working at the grass-root level and providing health services within the community are highly susceptible to contracting COVID-19 due to the lack of PPE kits. The government failed to make sufficient provisions for the health personnel posted in the isolation and quarantine centers. Additionally, these groups of female volunteers are also highly vulnerable due to the lack of proper training in the management of COVID $-19 . .^{42,43}$

\section{RECOMMENDATIONS FOR THE CURRENT CIRCUMSTANCES}

Nepal is an economically poor country and the annual budget of the nation largely depends on tourism, remittance, foreign grants and loans. With its limited resources, Nepal has to resolve the national and economic problems posed by the pandemic. The government of Nepal planned well to tackle this invisible enemy but there were serveral lacunas in the implementation of these plans. The country has to learn the strong lesson from this pandemic and should strengthen the infrastructure of healthcare settings, increase the quality and quantity of diagnostic laboratories, produce the adequate and trained healthcare workers and robust the health care delivery system in the nation. Majority of population of the nation is residence of the rural and semi-urban areas, the focus has to be prioritized even the community setup also. The government should emphasize in the better community network for awaring the citizen of Nepal. The country has to prepare for the possible recurrence or the second wave of pandemic. A robust health system with sufficient healthworkers equipped with necessary infrastructure and support is the immediate need of the hour.

\section{CONCLUSION}

The novel coronavirus unexpectedly evolved into a global pandemic in a very short span of time. The consequent effects of COVID-19 were handled differently by the different governing bodies of the respective nations. Due to a dearth of adequately trained health care staff accompanied with the under-developed medical facilities in Nepal. The country continues to strictly implement pharmacological and non-pharmacological measures to control the disastrous impact of COVID-19 at the provincial level. The poor health system of Nepal kept on combating with this pandemic with the limited human resource and shortage of health infrastructural in the nation.

\section{CONFLICT OF INTEREST}

The authors declare no conflict of interest.

\section{REFERENCES}

1. Nepal S, Nepal S, Shastry CS, Chand S, Nandakumar UP, Pant BD et al. Impact of COVID-19 on Mental Dimension of Health: A Sensitive Issue to be Addressed at the Earliest. Current Psychiatry Research and Reviews. 2020;16(3):158-66. https://doi.org/10.2174/2666082216999200918162639

2. Rothan HA, Byrareddy SN. The epidemiology and pathogenesis of coronavirus disease (COVID-19) outbreak. Journal of Autoimmunity. 2020;109:102433. 109https://www.sciencedirect.com/science/article/pii/ S0896841120300469\#sec4.

3. Cucinotta D, Vanelli M. WHO Declares COVID-19 a Pandemic. Acta biomed 2020;91(1):157-60.

4. Government of Nepal, Ministry of foreign affairs, Nepal Profile. 2020. Available from:https://mofa.gov.np/about-nepal/nepal-profile/,

5. Government of Nepal, Nepal Planning commission, Central Bureau of Statistics, Nepal in Figure 2019. 2019. Available from: https://cbs.gov.np/nepalin-figures-2019/

6. Government of Nepal, Ministry of Finance, Documents, English Economic Survey 2018-19. 2020. [English Version]. Available from: https://mof.gov.np/ uploads/document/file/compiled \% 20 economic \% 20Survey \% 20english \% 20 7-25_20191111101758.pdf.

7. Nepal Medical Council, Kathmandu. Registration Status. 2018. Available from: https://www.nmc.org.np/

8. Number, Subject, Level in Health Professionals Registered, Nepal Health Professional Council. 2018. Available from: https://www.nhpc.org.np/browse/ subject-wise-registration

9. Renewed status, Nepal Nursing Council. 2018. Available from: http://nnc.org $\mathrm{np} / \#$

10. Shankar P. Brain drain and practice locations of Nepalese medical students JMCJMS. 2018;5(2):1. Available from: https://www.nepjol.info/index.php/ jmcjms/article/view/19010

11. Bastola A, Sah R, Rodriguez-Morales AJ, Lal BK, Jha R, Ojha HC, et al. 
The first 2019 novel coronavirus case in Nepal. The Lancet Infectious Diseases. 2020;20(3):279-280.

12. Piryani R, Piryani S, Shah J. Nepal's response to Contain COVID-19 Infection. JNHRC, 2020;18(1):128-134.

13. Rajbhandari B, Phuyal N, Shrestha B, Thapa M. Air Medical Evacuation of Nepalese Citizen During Epidemic of COVID-19 from Wuhan to Nepal. J Nepal Med Assoc. 2020;58(222). https://doi.org/10.31729/jnma.4857

14. Asim M, Sathian B, Van TE, Mekkodathil A, Subramanya S, Simkhada P. COVID-19 Pandemic: Public Health Implications in Nepal. NJE. 2020;10(1):81720.

15. Anadolu Agency. Nepal halts Everest Expeditions over coronavirus fears. 2020 Available from: https://www.aa.com.tr/en/asia-pacific/nepal-halts-everestexpeditions-over-coronavirus-fears/1764742

16. Koirala S, Yadav BK, Yadav K, Koirala N. Status and Response till Third Stage of 2019 novel coronavirus disease (COVID-19) in Nepal. IJMR. 2020;6(6):130-44.

17. Marhatta SB, Paudel S, Aryal N. COVID-19 pandemic: What can Nepal do to Curb the Potential Public Health Disaster?. Journal of Karnali Academy of Health Science. 2020;3(1):1-4.

18. Nepal Telecom. Nepal Telecom puts Coronavirus awareness message in ring tones: Actions. 2020. Available from:https://www.clinicone.com.np/coronavirus-in-nepal-status-government-steps/

19. Report 59, 61, 63 and 67. Health Emergency Operation Center, Health Emergency and Disaster Management Unit (HEDMU), Ministry of Health and Population, Government of Nepal. 2020. Available from:https://heoc.mohp.gov. np/update-on-novel-corona-virus-covid-19/

20. Report 64, 68, 70. Health Emergency Operation Center, Health Emergency and Disaster Management Unit (HEDMU), Ministry of Health and Population, Government of Nepal. 2020. Available from:https://heoc.mohp.gov.np/updateon-novel-corona-virus-covid-19/

21. Health Emergency Operation Center, Health Emergency and Disaster Management Unit (HEDMU), Ministry of Health and Population, Government of Nepal. 2020. Available from:https://heoc.mohp.gov.np/update-on-novel-coronavirus-covid-19/ [Accessed on 15th June 2020]

22. Report 69, 70, 72, 75, 78, 86, 88, 94, 96, 100, 101, 103, 109. Health Emergency Operation Center, Health Emergency and Disaster Management Unit (HEDMU), Ministry of Health and Population, Government of Nepal. 2020. Available from:https://heoc.mohp.gov.np/update-on-novel-corona-virus-covid-19/

23. My republica, Rs 207 million collected in corona control fund. 2020. Available from: https://myrepublica.nagariknetwork.com/news/rs-207-million-collectedin-corona-control-fund/

24. The Himalayan Times, Provincial Government sets up fund to fight coronavirus. 2020. Available from: https://thehimalayantimes.com/nepal/provincialgovernment-sets-up-fund-to-fight-coronavirus/

25. Report 134, 135, 137, 139. Health Emergency Operation Center, Health Emergency and Disaster Management Unit (HEDMU), Ministry of Health and Population, Government of Nepal. 2020. Available from:https://heoc.mohp.gov. np/update-on-novel-corona-virus-covid-19/

26. Health Emergency Operation Center, Health Emergency and Disaster Management Unit (HEDMU), Ministry of Health and Population, Government of Nepal. Resource materials on Novel coronavirus-Situation Reports. Sit Report163. 2020. Available from:https://heoc.mohp.gov.np/update-on-novelcorona-virus-covid-19/

27. Health Emergency Operation Center, Health Emergency and Disaster Management Unit (HEDMU), Ministry of Health and Population, Government of Nepal. 2020. Resource materials on Novel coronavirus-Situation Reports. Sit Report172. 2020. Available from:https://heoc.mohp.gov.np/update-on-novelcorona-virus-covid-19/
28. Report 161, 163, 172. Health Emergency Operation Center, Health Emergency and Disaster Management Unit (HEDMU), Ministry of Health and Population, Government of Nepal. 2020. Available from:https://heoc.mohp.gov.np/updateon-novel-corona-virus-covid-19/

29. Report 179, 185. Health Emergency Operation Center, Health Emergency and Disaster Management Unit (HEDMU), Ministry of Health and Population, Government of Nepal. 2020. Available from:https://heoc.mohp.gov.np/updateon-novel-corona-virus-covid-19/

30. The Kathmandu Post, Collection of swab samples halted in Sudurpaschim. Available from: https://kathmandupost.com/sudurpaschim-province/2020/06/10/ collection-of-swab-samples-halted-in-sudurpaschim [Accessed on 2nd September 2020]

31. Dhungana RR, Aryal N, Adhikary P, et al. Psychological morbidity in Nepali crossborder migrants in India: A community based cross-sectional study. BMC Public Health.2019;19(1):1534. https://doi.org/10.1186/s12889-019-7881-z[20/06/2020]

32. Health Emergency Operation Center, Health Emergency and Disaster Management Unit (HEDMU), Ministry of Health and Population, Government of Nepal. Heoc.mohp.gov.np Resource materials on Novel coronavirus-Health Sector Emergency Response Plan, COVID-19 Pandemic. 2020. Available from:https://heoc.mohp.gov.np/update-on-novel-corona-virus-covid-19/

33. The Kathmandu Post, If Covid-19 cases continue to increase at current rate Nepal's health infrastructure could easily be overwhelmed, doctors warn Year??? Available from:https://kathmandupost.com/health/2020/05/13/if-covid19-cases-continue-to-increase-at-current-rate-nepal-s-health-infrastructurecould-easily-be-overwhelmed-doctors-warn

34. The Kathmandu Post daily, Thousands of Nepali migrants workers from Persian Gulf and Malaysia expected to return home soon. 2020. Available from: https://kathmandupost.com/national/2020/05/09/thousands-of-nepali-migrantworkers-from-persian-gulf-and-malaysia-expected-to-return-home-soon

35. Thomson Returns Foundation News, Nepal's top court orders rescue of migrant workers stranded abroad. 2020. Available from:https://news.trust.org/ item/20200417141312-4mwlj

36. The Kathmandu Post, Efforts on to quarantine evacuees in hotels across country. 2020. Available from:https://kathmandupost.com/national/2020/06/06/ efforts-on-to-quarantine-evacuees-in-hotels-across-country

37. Kumar $\mathrm{R}, \mathrm{Pal}$ R. India achieves $\mathrm{WHO}$ recommended doctor population ratio: $\mathrm{A}$ call for paradigm shift in public health discourse. JFMPC. 2018;7(5):841-844.

38. Shankar P. Brain drain and practice locations of Nepalese medical students. JMCJMS. 2017:5(2):1-4.

39. The Rising Nepal. Active Cases of COVID-19 Might Surge to 39,000 in 10 Days: MoHP. 2020. Available from: https://risingnepaldaily.com/main-news/activecases-of-covid-19-might-surge-to-39000-in-10-days-mohp

40. The Kathmandu Post, Rights watchdog urges government to follow WHO quarantine practices. 2020. Available from:https://kathmandupost.com/ national/2020/05/18/rights-watchdog-urges-government-to-follow-whoquarantine-practices

41. Nepali Times, Quarantine guidelines impossible to meet: local governments. 2020. Available from:https://www.nepalitimes.com/latest/quarantineguidelines-impossible-to-meet-local-governments/

42. Sharma S, Bhatta J. Public health challenges during the COVID-19 outbreak in Nepal: A commentary. Journal of Health Research. 2020;30(4):373-6.

43. Nepal S, Aryal S. COVID-19 and Nepal: A Gender Perspective. J Lumbini Med Coll. 2020;8(1):121-2.

Article History: Submission Date : 05-04-2021; Revised Date : 01-05-2021; Acceptance Date : 17-06-2021.

Cite this article: Pant BD, Chand S, George SM, Nandakumar UP, Khanal P, Shastry CS, et al. Lacunas in the Preparation of Nepal for COVID-19 till the Third Stage of Disease Transmission. J Young Pharm. 2021;13(2):91-6. 